\title{
Intra-national business (IB)
}

\author{
Mike W. Peng ${ }^{1} \cdot$ Sergey Lebedev ${ }^{2}$
}

Published online: 22 March 2017

(C) Springer Science+Business Media New York 2017

Almost by definition, international business (IB) research uses the nation-state (or country) as a fundamental building block. From its very beginning, this research has used the country as the basic level of analysis. Since the 1980s, the popularity of Geert Hofstede's work, which explicitly adopts the nation-state as a unit of analysis, has consolidated the dominance of this approach.

As scholars look for new research directions to enhance the sophistication and reach of IB research, we argue that it is time to incorporate intra-national (or sub-national) differences in our research endeavors. ${ }^{1}$ Recent IB research on sizable emerging economies has highlighted the importance to account for sub-national institutional variance (Chabowski, Hult, Kiyak, \& Mena, 2009). Beyond emerging economies, significant intra-national differences (or within-country diversity) in developed economies are also found to be significant drivers of IB behavior (Dow, Cuypers, \& Ertug, 2016; Monaghan, Gunnigle, \& Lavelle, 2014). It seems that we are witnessing the beginning of a new era of IB research, with a growing interest in intra-national differences.

\section{Intra-national institutional differences}

From a theoretical standpoint, IB's focus on international differences reflects a deep and enduring interest in the differences in institutions around the world and in the impact of

\footnotetext{
${ }^{1}$ In this small but rapidly expanding literature, the terms "intra-national differences," "sub-national differences," and "within-country diversity" have been used almost interchangeably. Given our interest in promoting "IB" research, we prefer "intra-national business."
}

Mike W. Peng

mikepeng@utdallas.edu

Sergey Lebedev

slebedev@sfsu.edu

1 Jindal School of Management, University of Texas at Dallas, 800 W. Campbell Road, SM 43, Richardson, TX 75080, USA

2 College of Business, San Francisco State University, 1600 Holloway Avenue, San Francisco, CA 94132, USA 
these institutional differences on IB behavior and performance. Such an institutionbased view (Meyer \& Peng, 2016; Peng, Wang, \& Jiang, 2008) can be meaningfully extended, broadened, and deepened to probe intra-national differences.

A stream of recent IB research has identified substantial intra-national differences as a driver of firm behavior and performance. As more scholarly attention is given to emerging economies - in particular, large, diverse, and institutionally complex countries such as Brazil, Russia, India, China, and South Africa (BRICS) - recognizing substantial intranational differences in these emerging economies is needed for a more fine-grained analysis of the influence of institutions on firms. Among BRICS, China's size and complexity has attracted significant attention (Gong, Chow, \& Ahlstrom, 2011; Poncet, 2005), resulting in a sizable literature on the influence of its intra-national differences.

In terms of foreign direct investment (FDI), Blanc-Brude, Cookson, Piesse, and Strange (2014) document that the attractiveness of a particular sub-national region in China to FDI not only depends on its own attributes, but also on its neighboring regions' attractiveness. Yi, Chen, Wang, and Kafouros (2015) highlight the impact of sub-national region-specific institutions on the spillover effects of FDI. Chan, Makino, and Isobe (2010) and Ma, Tong, and Fitza (2013) find that sub-national regions are significant in explaining foreign subsidiary performance in China. Finally, Sun, Peng, Lee, and Tan (2015) document that Chinese firms from regions more open to inward FDI are more motivated to engage in outward FDI.

In research on international joint ventures (IJVs), Shi, Sun, and Peng (2012) and Shi, Sun, Pinkham, and Peng (2014) report that in more institutionally developed Chinese provinces, local firms with high network centrality are more likely to be chosen as IJV partners by foreign entrants, while in less developed regions, firms with brokerage positions are relatively more attractive IJV partners. Lu and Ma (2008) reveal that an IJV's performance in China in part depends on whether its location has imposed restrictions on FDI.

Researchers interested in corporate governance and corporate strategy have also probed into intra-national differences within China. In Chinese regions with more developed institutions, Li and Qian (2013) find that the negative influence of the degree of control (share in a firm's equity) of the largest shareholder on the probability of an acquisition of this firm is lower, and He and Fang (2016) report that the link between executive pay and firm performance is stronger. Peng, Sun, and Markóczy (2015) identify a strong relationship between CEOs' international experience and executive compensation in Chinese regions with a high level of marketization. Sun, Peng, and Tan (2017) reveal that the relationship between CEOs' international experience and a propensity for engaging in international diversification (as opposed to more product diversification) is contingent upon whether these firms are headquartered in Chinese regions with a high degree of economic freedom.

In Vietnam, Meyer and Nguyen (2005) find that intra-country differences influence inward FDI locations and entry modes. Their findings indicate that access to scarce resources (associated with more developed sub-national institutions) facilitates FDI, especially greenfield entry. In addition, the prevalence of state-owned enterprises (associated with less developed sub-national institutions) in a region leads to a preference for IJVs over greenfields.

In Korea, Lee, Hong, and Makino (2016) highlight major differences between service and manufacturing multinationals when making FDI decisions in sub-national 
regions. Specifically, service multinationals are more influenced by demand-side considerations in sub-national regions, and manufacturing multinationals by supply-side considerations.

In India, Dheer, Lenartowicz, and Peterson (2015) identify nine culturally distinct sub-national regions. Nunnenkamp, Liu, and Bickenbach (2014) report that subnational differences have contributed to the increasing concentration of FDI in the top six regions (such as Bangalore, Delhi, and Mumbai) vis-à-vis the rest of the country. The better developed market-supporting institutions in these top regions seem to be behind their attraction.

In Mexico, Montiel, Husted, and Christmann (2012) explore the influence of subnational differences in corruption on the signaling value of private certification systems (such as ISO standards). They distinguish policy-specific and general corruption, and find that while policy-specific corruption in a region increases the likelihood of obtaining certification by a firm, general corruption decreases this likelihood.

In Russia, Lebedev and Peng (2016) explore how sub-national institutional differences moderate the relationship between research and development (R\&D) and firm performance. They find that, while overall $R \& D$ intensity has a negative association with performance, this relationship is weakened by better market-supporting institutions in a region (where a firm's headquarters is located) and, conversely, strengthened by higher levels of corruption in a region.

While the research reviewed above focuses on emerging economies, substantial subnational differences are also found in work dealing with developed economies. In Ireland, Monaghan et al. (2014) report that different sub-national institutions (such as local governments and trade unions) may facilitate or inhibit foreign market entries. In Italy, Laursen, Masciarelli, and Prencipe (2012) find that firms located in regions characterized by a high level of social capital (with more active informal interactions among individuals) have higher propensity to innovate. In the United States, Chan et al. (2010) show that the sub-national region (specifically, state) is significant in explaining variance in the performance of foreign subsidiaries. In addition, they also show that in the United States (a developed economy) this influence is weaker than that in China (an emerging economy). Also in the United States, Dass, Nanda, and Xiao (2016) reveal that US firms have significantly lower value and informational transparency when located in regions within the country that are more corrupt.

Beyond individual countries, Dow et al. (2016) leverage a database consisting of 67 acquirer countries and 69 target countries (including both developed and emerging economies). They find that within-country diversity in acquirer and target countries has a significant impact on cross-border mergers and acquisitions (M\&A) decisions. As researchers now increasingly look at M\&As in and out of emerging economies (Lebedev, Peng, Xie, \& Stevens, 2015; Mutlu, Wu, Peng, \& Lin, 2015), pathbreaking findings reported by Dow et al. (2016) provide much needed motivation to investigate intra-national differences behind such decisions.

Clearly, sub-national differences are real and substantial, as long as a country is not very small and its "national" culture is not so homogenous. The cumulative evidence suggests that significant mileage can be gained by probing intra-national differences in IB research. Having published a series of interesting papers such as Gong et al. (2011), He and Fang (2016), Lee et al. (2016), and Sun et al. (2017), the Asia Pacific Journal of Management is ideally positioned to take advantage of this cutting-edge research agenda. 


\section{The danger of being a car market researcher in New York}

Once upon a time, a (non-US) automaker sent a car market researcher to New York for a week trying to understand Americans' car consumption pattern. After she landed at the airport, she took a ride on a taxi and checked into her hotel in Manhattan. Then she spent her entire week in Manhattan, diligently observing how Americans use their cars. Upon return, she wrote a market research report based on her first-hand observation. Her conclusion: Americans do not like cars. Specifically, individual households do not like to purchase and operate cars. Because almost every car she saw in the streets of New York City (specifically Manhattan) was a taxi or limousine, she reasoned that private car ownership and consumption is extremely limited in the United States. Her recommendation? Do not bother to target individual Americans as potential car buyers - they obviously love to take the taxi or ride the subway. Her conclusion is: Market entry efforts to the "US market" should focus on fleet sales, especially sales to taxi cab and limousine companies.

We are sure many readers are laughing at this point. However, the fictitious market researcher in New York is not alone. She has a lot of colleagues in practice. A lot of them are hard working in Sao Paulo, Shanghai, and St. Petersburg, trying to understand, respectively, the "Brazilian," "Chinese," and "Russian" markets. Like their colleague in New York, their blunder of course is that they never bother to understand the "real" Brazil, China, and Russia by not bothering to step out of the main business centers in these countries.

As a community, IB researchers should strive to have a broader and more sophisticated view than the hard-working market researcher in New York. Yet, so many of our measures in so many of our data bases come from one data point in one country (often from one city or region). Then we often make the heroic assumption that such data (from firms and people in one city or region) represent the central tendency or average of a country. As IB research marches in the twenty-first century, we argue that it is time to graduate from its adolescence by focusing more attention and energy on intra-national business, which, by definition, is also "IB."

Acknowledgements We thank Jane Lu (Editor-in-Chief) for editorial guidance, and David Ahlstrom and Jingtao Yi for helpful discussions. This work is supported in part by the Jindal Chair at UT Dallas and the College of Business at SFSU.

\section{References}

Blanc-Brude, F., Cookson, G., Piesse, J., \& Strange, R. 2014. The FDI location decision: Distance and the effects of spatial dependence. International Business Review, 23: 797-810.

Chabowski, B. R., Hult, G. T. M., Kiyak, T., \& Mena, J. A. 2009. The structure of JIBS's social network and the relevance of intra-country variation: A typology for future research. Journal of International Business Studies, 41: 925-934.

Chan, C. M., Makino, S., \& Isobe, T. 2010. Does sub-national region matter? Foreign affiliate performance in the United States and China. Strategic Management Journal, 31: 1226-1243.

Dass, N., Nanda, V., \& Xiao, S. C. 2016. Public corruption in the United States: Implications for local firms. Review of Corporate Finance Studies, 5: 102-138.

Dheer, R., Lenartowicz, T., \& Peterson, M. F. 2015. Mapping India’s regional subcultures: Implications for international management. Journal of International Business Studies, 46: 443-467. 
Dow, D., Cuypers, I. R. P., \& Ertug, C. 2016. The effects of within-country linguistic and religious diversity on foreign acquisitions. Journal of International Business Studies, 47: 319-346.

Gong, Y., Chow, I. H.-s., \& Ahlstrom, D. 2011. Cultural diversity in China: Dialect, job embeddedness, and turnover. Asia Pacific Journal of Management, 28(2): 221-238.

He, L., \& Fang, J. 2016. Subnational institutional contingencies and executive pay dispersion. Asia Pacific Journal of Management, 33(2): 371-410.

Laursen, K., Masciarelli, F., \& Prencipe, A. 2012. Regions matter: How localized social capital affects innovation and external knowledge acquisition. Organization Science, 23: 177-193.

Lebedev, S., \& Peng, M. W. 2016. Sub-national institutional differences and R\&D-performance relationship in an emerging economy. Working paper, University of Texas at Dallas.

Lebedev, S., Peng, M. W., Xie, E., \& Stevens, C. E. 2015. Mergers and acquisitions in and out of emerging economies. Journal of World Business, 50: 651-662.

Lee, I. H., Hong, E., \& Makino, S. 2016. Location decisions of inward FDI in sub-national regions of a host country: Service versus manufacturing industries. Asia Pacific Journal of Management, 33(2): 343-370.

Li, J. T., \& Qian, C. 2013. Principal-principal conflicts under weak institutions: A study of corporate takeovers in China. Strategic Management Journal, 34: 498-508.

Lu, J. W., \& Ma, X. 2008. The contingent value of local partners' business group affiliations. Academy of Management Journal, 51: 295-314.

Ma, X., Tong, T. W., \& Fitza, M. 2013. How much does sub-national region matter to foreign subsidiary performance? Evidence from Fortune Global 500 corporations' investment in China. Journal of International Business Studies, 44: 66-87.

Meyer, K. E., \& Nguyen, H. V. 2005. Foreign investment strategies and sub-national institutions in emerging markets: Evidence from Vietnam. Journal of Management Studies, 42: 63-93.

Meyer, K. E., \& Peng, M. W. 2016. Theoretical foundations of emerging economy business research. Journal of International Business Studies, 47: 3-22.

Monaghan, S., Gunnigle, P., \& Lavelle, J. 2014. "Courting the multinational": Sub-national institutional capacity and foreign market insidership. Journal of International Business Studies, 45: 131-150.

Montiel, I., Husted, B. W., \& Christmann, P. 2012. Using private management standard certification to reduce information asymmetries in corrupt environments. Strategic Management Journal, 33: 1103-1113.

Mutlu, C. C., Zhan, W., Peng, M. W., \& Lin, Z. J. 2015. Competing in (and out of) transition economies. Asia Pacific Journal of Management, 32(3): 571-596.

Nunnenkamp, P., Liu, W.-H., \& Bickenbach, F. 2014. Regional concentration of FDI involves trade-offs in post-reform India. Columbia FDI Perspectives, 118: 1-3.

Peng, M. W., Wang, D. Y. L., \& Jiang, Y. 2008. An institution-based view of international business strategy: A focus on emerging economies. Journal of International Business Studies, 39: 920-936.

Peng, M. W., Sun, S. L., \& Markoczy, L. 2015. Human capital and CEO compensation during institutional transitions. Journal of Management Studies, 52: 117-147.

Poncet, S. 2005. A fragmented China: Measure and determinants of Chinese domestic market disintegration. Review of International Economics, 13: 409-430.

Shi, W. S., Sun, S. L., \& Peng, M. W. 2012. Sub-national institutional contingencies, network positions, and IJV partner selection. Journal of Management Studies, 49: 1221-1245.

Shi, W. S., Sun, S. L., Pinkham, B., \& Peng, M. W. 2014. Domestic alliance network to attract foreign partners: Evidence from international joint ventures in China. Journal of International Business Studies, 45: 338-362.

Sun, S. L., Peng, M. W., Lee, R. P., \& Tan, W. 2015. Institutional open access at home and outward internationalization. Journal of World Business, 50: 234-246.

Sun, S. L., Peng, M. W., \& Tan, W. 2017. Institutional relatedness behind product diversification and international diversification. Asia Pacific Journal of Management. in press. doi:10.1007/s10490-016-9498-4.

Yi, J., Chen, Y., Wang, C., \& Kafouros, M. 2015. Spillover effects of foreign direct investment: How do region-specific institutions matter?. Management International Review, 55: 539-561.

Mike W. Peng (PhD, University of Washington) is the Jindal Chair of Global Strategy at the Jindal School of Management, University of Texas at Dallas. He is one of the top 70 most cited scholars in the field of business and economics who are listed in The World's Most Influential Scientific Minds (compiled by Thomson Reuters). He was Editor-in-Chief (2007-2009) of the Asia Pacific Journal of Management, where he currently serves as Consulting Editor.

Sergey Lebedev ( $\mathrm{PhD}$, University of Texas at Dallas) is an assistant professor of international business at San Francisco State University. His research interests include institutions, interfirm networks, and political ties. 